Матеріали Всеукраїнської науково-практичної конференчії «Актуальні питання діагностики, лікування, раціональної фармакотерапії, диспансеризації та реабілітації в практиці сімейного лікаря» DOI

\title{
КЛІНІКО-ІМУНОЛОГІЧНІ ОСОБЛИВОСТІ ПЕРЕБІГУ ВНУТРІШНЬОУТРОБНИХ ВІРУСНИХ ІНФЕКЦІЙ У НОВОНАРОДЖЕНИХ
}

@І. І. Редько, О. М. Чакмазова

\author{
ДЗ «Запорізька медична академія післядипломної освіти МОз України»
}

На сучасному етапі відкритими залишаються питання про системне вивчення імунної відповіді при внутрішньоутробних вірусних інфекціях (ВВI) з різними клінічними варіантами перебігу, що обумовлює обгрунтування своєчасного специфічного лікування.

Мета - визначити клініко-імунологічні особливості перебігу ВВІ у новонароджених (НH).

Матеріали та методи. Проведено клініколабораторне обстеження 834 матерів та їх хворих НН з групи ризику по ВУІ. Предметом поглибленого дослідження стали $224 \mathrm{HH} з$ верифікованими BВI, контрольна група - 30 здорових НН. До плану обстеження включено: етіологічна верифікація BВI методами прямої імунофлуоресценції, імунохроматографічного аналізу, серодіагностики, полімеразної ланцюгової реакції, бактеріологічного обстеження; вивчення клініко-анамнестичних особливостей перебігу ВBI; дослідження стану показників клітинної та гуморальної ланок імунітету, інтерферонового статусу.

Результати дослідження. Серед 224 дітей з BBI верифіковано: мікст-вірусно-вірусні інфекції - у 77 (34,4\%), мікст-вірусно-бактеріальні-у 62 (27,7\%), мікст-вірусно-TORCH - у 53 (23,6 \%) та моновірусні у 32 (14,3 \%). При верифікації етіологічного збудника вірус грипу А визначено у 15,6 \%, парагрипу - у $20,5 \%$, аденовірус - у 40,6 \%, РС-вірус - у 27,2 \%, ен- теровірус - у 48,2 \%, ЦМВ - у 56,6 \%, ВПГ - у 22,6\%. Клінічними формами BBI $€$ генералізована (4,5 \%), церебральна (5,4\%), вісцеральна (73,6\%), локалізована (5,4 \%), субклінічна (10,7 \%). Найбільш несприятливий перебіг інфекцій з летальністю (11,3%) відзначено при мікст-вірусно-бактеріальних інфекціях. При ВВІ відмічено зниження відносного вмісту СД3, СД4, СД19, коефіцієнта супресії, зниження функції активності лімфоцитів (ФЧН, НСТстимульований) на тлі зниження ІФН-а та ІФН-ү при всіх мікст-формах інфекцій зі статистично значущою різницею з показниками контрольної групи $(p<0,05)$. Найтяжче ушкодження імунної системи виявлено при мікст-вірусно-TORCH-інфекціях: СД3$(53,8 \pm 4,5) \%$, СД4 - $(33,3 \pm 4,0) \%$, СД $19-(19,5 \pm 4,1) \%$, коефіцієнт супресії - $(1,47 \pm 0,2), \lg$ - $(3,6 \pm 1,1)$ г/л, ФЧН - $(4,7 \pm 1,4)$, індекс завершеності фагоцитозу $(0,84 \pm 0,2) \%$, НСТ-стимульований- $(19,2 \pm 1,9) \%$. Найбільше зниження ІФН-а та ІФН-ү відзначено при вірусно-TORCH-інфекціях (IФН-а - $(1,23 \pm 2,1)$ пг/мл проти $(4,88 \pm 2,9)$ пг/мл у контрольній групі; ІФН-ү $(3,2 \pm 4,9)$ пг/мл проти $(7,1 \pm 3,0)$ пг/мл у контрольній групі).

Висновки. Реакція імунної системи при ВВІ супроводжується змінами клітинної та гуморальної ланок імунітету, інтерферонового статусу, що потребує своєчасного призначення специфічної та імунокоригуючої терапії. 